\title{
The Determinants of Banks' Capital Ratio in Developing Countries: Empirical Evidence from Tunisia
}

\author{
Mohamed Romdhane \\ University of Tunis- Institut Supérieur de Gestion \\ 41, Rue de la liberté, Le Bardo 2000, Tunis, Tunisia \\ moromd@gmail.com
}

\begin{abstract}
In this paper, we try to study the determinants of the banks' capital ratio in an emerging country. To do so, we model the relationships between some variables of the banks and this ratio. Our aim is to explain its high level. We try also to answer to a new question. Is it affected by the same factors in the emerging countries as in the industrialized ones?

The sample is composed of 18 banks. The data are half yearly. The period sample is from 2002 to 2008.

We find that the interest margin and the risk affect strongly the capital ratio. They explain the excess of the capital held by the Tunisian banks. So, this excess is not explained only by regulatory pressures. The deposit variability and the intermediation rate have the same sign. But, the equity cost and the deposits ratio both have a negative impact. The main determinants are the same for all the countries.
\end{abstract}

Keywords: Capital ratio, commercial bank, capital determinants, capital structure, developing countries.

\section{Introduction}

The financial intermediation specificity and the regulation make the commercial banks different from the non financial firms. Marques and Santos (2003) stated that capital regulation is the first external determinant of the banks' capital structure. Many other authors arrived at the same conclusion. This may be true in developed countries. But in developing small countries, there are no enough studies that show this influence. If the Basel rules are imposed on the commercial banks over the world, their influences must be the same, whatever the size of the banks. Consequently, only one theoretical approach must be observed in the banking industry.

The Commercial banks hold capital because they are required to do so by authorities. Nevertheless, the capital level is determined by the bank requirements, by the risk and by the capital cost. With high equity cost, bank managers try to hold the minimum capital required. However, if the risk taken is high they must increase the capital.

Schaeck and Čihák (2007) stated that if banks operate in a competitive environment, they tend to hold a higher capital ratio. This is consistent with the idea that if an economy is bank-based, the competition degree in the capital markets is week. This may be the case of the Tunisian banking market.

Murinde and Yaseen (2004) found that the capital requirements affect commercial banks' capital decisions in the MENA region. They said that regulatory pressure did not induce banks to increase their capital.

Brewer et al. (2008) demonstrated that if the banking sector is relatively small, the banks maintain a higher capital adequacy ratio. When the authorities practice prompts corrective actions, this ratio is high too.

The capital structure of small banks operating in a local market has not been enough investigated. So, we will try to analyze empirically the validity of the banks' capital theory in an emerging country. This will allow us to test the universality of the rules and the relationships demonstrated by the previous studies.

We will analyze those relationships in the Tunisian commercial banks by applying a linear model. We insert $52 \mid \mathrm{P}$ a g e

WwW.iiste.org 
two new variables not tested in previous empirical studies: The deposit variability and the intermediation rate which represent the banking activity. Rapid deposits variability characterizes the Tunisian banks. It may directly affect their capital ratio.

This paper is organized as follows. In the next section, we will present the Tunisian banking characteristics. The third section is devoted to the literature of capital structure in commercial banks. In the fourth section, we will analyze empirically the determinants of capital ratio in Tunisian banks. The main results are drawn in the fifth section. The conclusion constitutes the sixth section.

\section{Tunisian Banking Characteristics}

The Tunisian banking industry is small. In 2010, there are 30 small domestic commercial banks. They are based in Tunis and big towns. The three first largest banks are state owned. It is characterized by its high degree of concentration. In fact, the public banks hold more than half of total market share. In this case, the authorities can easily influence their strategies and their decisions. As displayed in Table 1, large public banks hold often less capital than the private ones. After the reforms, the Tunisian banks have adopted a new governance system. It is the same as those of European banks. They are well managed and well organized.

Tunisia's banks are actively involved with European banks. In addition to financial flows, some foreign banks have shares in the capital of Tunisian banks.

Capital requirements in Tunisia have been dictated by Basel I. Basel I rules had started to be applied in 1992. It was $5 \%$ of risk weighted assets, and then it rose to $8 \%$ in 1999. The recorded rates were between $8.4 \%$ and $13.4 \%$. They were so high.

During the sample period, the annual capital ratio was as shown in Table 1.

For small as for large banks, the capital ratio was often higher than that required one. As noted by Berger et al. (2008), the excess of equity makes it difficult to any analyst to tell how banks manage their capital. For Tunisian banks, the problem of adjustment did not arise. This is due to the banks' policies. They adopted risky loan strategies, and they increased their equity to escape the regulator pressures.

Table 1 shows that since 2004, the private banks' ratio is higher than that of public banks. This can be explained by the large size of the stated owned banks. Their size had notably increased after their mergers with the development banks. Moreover, they are often sustained by the authorities.

It is noted that during the same period, Trier 1 was higher than the minimum imposed by Basel I.

The notable increase of the capital ratio is due to the 2001 law. All the Tunisian banks increased their capital by issuing of new shares. During the last decade, their average ROE was $13 \%$. Their rate of earnings' retention was high. This had led to an increase in equity.

As it has been pointed out above, the Tunisian banks adopt new methods of management, and they apply the international prudential rules. However, they are not as large and powerful as the American or the European banks. Compared to those banks, Tunisian banks are too small. Their total asset is equal or lower than these of a single bank in a developed country. In Tunisia, the banking sector is small. It has some characteristics: the number of banks is very limited, the dominant banks are public and the concentration degree is high. With these specificities, the Tunisian banks may differ from those of other countries.

These specificities lead us to ask several questions: If the banks' capital ratios were often high, why did the authorities impose the Basel ratio? Does the level of equity constitute a result of other factors specific to Tunisian banks? Are the determinants of capital ratio the same in emerging countries as in developed ones?

The capital structure of small banks operating in a local market has not been enough investigated. So, we will try to analyze empirically the validity of the banks' capital theory in an emerging country. This will allow us to test the universality of the rules and the relationships demonstrated by the previous studies.

$\mathbf{5 3} \mid \mathrm{P}$ a g e

www.iiste.org 


\section{Banks' Capital Structure}

\subsection{Theoretical Fundamentals}

For the firms, two main alternative theories are identified for their capital structure: the Trade-off and the Pecking Order. The first holds that the capital structure is determined by the trade off between the benefits and the debts ' costs. The second holds that the short run costs exceed the benefits of adjusting the capital structure. Thus, firms rely first on retained earnings and then on the debts. They issue stocks only if the marginal costs of the additional debts exceed the costs of this new issuing. The commercial banks prefer first the retained earnings. The pecking order theory suggests that the dividend provides a good signal about the future prospects of the firm. So, the managers will issue new equity as there is less information asymmetry in the capital market.

For the banks, the subjects relating to the problems of the liquidity creation and the loan risk were considered a priority for a long time. The capital structure of the banks has not been considered as an important topic. Marques and Santos (2003) considered that the studies on the bank's capital are very limited. In fact, the issue has not been treated for long years. There are two reasons to think that the capital ratio does not deserve to be studied. The first is the absence of limits for the deposits. The second is the ease of the access to the capital market.

Baltensperger (1973) stated that the banks maximize their profit when the mix liabilities equity is optimal. Then, they have to hold an appropriate capital ratio. In this case, their deposits and their loan ratios are optimal too.

Kohen and Santomero (1980) demonstrated that a regulation based only on the "equity /assets" ratio cannot necessarily lead to the expected results. They proposed a ratio with weighted risk assets. They cited other determinants: The deposit growth, the asset size and the revenue.

For Brewer et al. (2008), under regulation, the capital ratio may be determined by one or other of these theories. The trade-off assumptions with binding regulation have a testable prediction. In instance, if there is only one ratio, banks should operate above the required minimum. The Pecking order hypothesis assigns a significant role to the government rules.

With nonbinding regulation hypotheses, the both theories have the same results. They retain that the market forces have an important role. In fact, they determine the cushion banks seek to maintain their capital over the minimum.

Gropp and Heider (2007) found that the determinants of the capital of the firms are also significant for the banks.

\subsection{Banking Capital Theory After Basel I}

After the application of the Basel I rules, the issue of the capital ratio attracted the researchers in developed countries. In the last two decades, several studies are carried out. Their aim is to explain the relationships between this ratio and some internal and external variables.

Berger et al. (1995) stated that the theory of capital structure of the firms cannot be fully applied to the financial institutions. This is due to the regulation. They also pointed to the importance of external factors that affect the capital of the banks.

Diamond and Rajan (2000), affirmed that the high capital reduces the creation of liquidity by the bank. But it enables them to be solid and to avoid the bankruptcy.

Why do commercial banks hold often more capital than the minimum required? Does it mean that their economic capital is determined by the intermediation volume? Or it is determined by their risk level?

For Alfon et al. (2005), the capital adequacy is a positive signalling for the market and for all the partners to

$\mathbf{5 4 | P}$ a g e

www.iiste.org 
modify their perceptions. Asarkaya and Ozcan (2007) pointed out that when economic growth is high, the banks make more profit. This profit may contribute to their capital increase. So, they hold more capital. These authors stated that with the Basel I accord, the notion of capital used in the approach of risk based capital could not adequately explain the bank's capacity to compensate the losses. They also pointed out that the risk criteria that they employed were not satisfactory. Certainly, the managers of the commercial banks realized this reality. To guard themselves against the risks, they take care that the capital ratio is high.

Gropp and Heider (2007) found that the profitable banks tend to have relatively more equity. Their findings are consistent with the prediction of the pecking order theory.

Kleff and Weber (2008) demonstrated that the capital level is positively correlated with the profit. The accumulation of the profit breeds the capital growth.

Brewer et al. (2008) pointed out that for the banks, the use of the equity should be determined by the same set of forces that influence other firms. But the combined impacts of the government safety net policies and the regulation must be taken in account.

The findings of Ahmad et al. (2009) for Malaysian banks are inconsistent with the previous results. They demonstrated that the earnings affect negatively the capital ratio. For them, these findings contradict the view that a high ratio (earnings/franchise value) provides the managers an easy access to equity. High earnings may cause bank management to reduce capital cushioning accordingly.

Most of the previous studies demonstrated that the regulation is not the unique determinant of the capital ratio. There are many other macroeconomic and banks' specific Determinants. They are rather numerous and they have a power in explaining the variation of this ratio.

Further the regulation, the main determinants are: The profitability, the capital cost, the risk, the deposits and the asset size.

\section{Empirical analysis of the Tunisian banking industry}

\subsection{Sample and Data}

We employed half-yearly data from the Tunisian banking industry for the period January 2002-December 2008. The data are obtained from financial statements published by banks and from quarterly and annual reports of central bank of Tunisia. This period was selected to observe the determinants of the bank capital ratios after the 2001 reform. Many banks have increased their capital after this reform. There were many mergers and, during this period, strange commercial banks became shareholders in Tunisian banks.

This factor makes it difficult to adjust the previous data to make them comparable to the data collected after 2001. For all relating variables to be used in our regressions, each bank must have data for seven years.

In addition, we excluded two banks recently created, the development banks and all other development banks recently transformed into deposit banks. After this selection, our final sample contains 18 commercial banks.

For empirical regression, the equity cost is annual because the dividend is annual. We consider that for the first half year, the cost of equity is the same as that of the second period of the previous year. The cost for the second half year is determined for the same year. With this temporal shift, each cost will be used twice times, but in two different years.

\subsection{Descriptive Statistics}

Tables 2 and 3 provide descriptive statistics for the independent variables.

The means of the variables are presented in Table 2 by six months. The banks of our sample have an average of capital ratio of $11.37 \%$.

The Risk was very high although its decrease from $18.6 \%$ in the first half of 2002 , to $16.4 \%$ in the second $\mathbf{5 5} \mid \mathrm{P}$ a g e

www.iiste.org 
half of 2008. The Tunisian commercial banks finance more and more the risky activities. For the sample period, its average is $17.3 \%$.

The equity cost decreased over time from $12.8 \%$ in 2002 to $9.51 \%$ in the second half of 2008 . This is due to the increase more than proportional of equity compared to the dividend.

The mean of the ratio "term deposits/demand deposits" is around 55\% and it has increased since 2002. In 2008 , it is around $65 \%$. The stability of the deposits improved, but their average cost increased. The interest margin rate recorded small semi-annual increases and its average is around $8.73 \%$ during the sample period.

The intermediation rate has improved for all the banks, essentially for the large banks. Its average is 74\%.

The size of the assets of the banks of our sample has increased over the period 2002 - 2008.

Demand deposit variability has increased with constant rhythms. This means that the share of the deposits in liabilities has dropped. It was $48.23 \%$ in the first half of 2002 and it increased to $63.74 \%$ in 2008, for all the commercial banks. Its average is $57.67 \%$.

The average capital ratio of the banks has been higher than the minimum required over time. It was around $10.6 \%$ in 2002 and around $11.2 \%$ at the end of 2008. Its mean is around $10.93 \%$.

Table 4 displays the correlation matrix of the variables of the model. It shows that three variables are negatively correlated with capital ratio. They are the deposit ratio, the equity cost and the asset size. The negative sign of the variable size means that the larger banks have lower capital ratio. All the other variables are positively correlated with the capital.

\subsection{The Model}

The general empirical regression is specified as follows:

$$
\mathrm{Y}_{\mathrm{it}}=\lambda_{0}+\sum \lambda_{\mathrm{j}} \mathrm{X}_{\mathrm{jit}}+\varepsilon_{\mathrm{it}}
$$

Where,

$\mathrm{Y}_{\mathrm{it}}$ is the capital ratio in time $\mathrm{t}$ for the bank $\mathrm{i}$

$\lambda_{0}$ is a constant

$\mathrm{X}_{\mathrm{jit}}$ is the $\mathrm{jth}$ explanatory variable for the ith bank in period $\mathrm{t}$

$\lambda_{\mathrm{j}}$ is the parameter to estimate

$\varepsilon_{\text {it }}$ is the error term

\subsubsection{Empirical Specification and Methodology}

Our model helps to determinate the capital ratio of bank $i$ at time t. We will use the standard capital determinants as explanatory variables. Market value is used only for equity. The equity cost is approximated by the ratio "dividend/equity". The deposit ratio measures the structure of the deposits.

To allow a better comparison, the assets must be adjusted by the consumer price index.

We exclude the external economic variables. They may be correlated with the bank specific factors. The variable regulation is excluded too. Its elimination is justified by the very high capital ratios during the sample period. This will allow us to highlight the effects of the banks' specific variables.

We propose two new bank specific variables: The intermediation rate and the deposit variability.

\subsubsection{Deposit Variability}

The variability of demand deposits has an impact on the liquidity of the banks and on their insolvency risk. A high variability may be a synonym of the weakness of the financial resources. It is the case when the

56|P a g e

www.iiste.org 
proportion of the term deposits is low. If this situation is accompanied with a rather great loans portfolio, the banks would be obliged to increase their capital.

This variable can be approximated by the ratio "outflows of deposits/inflows of deposits" of the period. When outflows are higher than inflows, the variability is speedy.

The analysis of the deposits' movements of all the banks shows that for the households and the small savers, it increases remarkably in summer and during the month of Ramadan and at the end of the year. For all banks' customers, this variability is cyclical. It has an influence on the structure of loans. Indeed, the faster is this variability, the more the banks grant short-term credits.

More there are cheaper deposits, more intermediation brings back profits. But when the share of deposit decreases, the banks will borrow at a higher cost. This decrease can be compensated by debts and by additional equity.

In our model, we retain the average of the ratios recorded for each six month period. It is expected that it influences negatively the capital ratio.

\subsubsection{Intermediation Rate}

This variable is determined by the ratio "Total loans / total deposits". It represents the volume of activity of the banks. The more this rate is high, the more the bank are efficient, and the more it is able to profit from economies of scale.

A high intermediation rate means that the bank grants more loans. Its liquidity risk and its loans losses may be high. We expect that this rate influences positively the capital ratio.

\subsubsection{Panel equation}

It is written as follows:

$$
\begin{aligned}
& \text { Capital }_{i t}=\lambda_{0}+\lambda_{1} \text { RISK }_{\mathrm{it}}+\lambda_{2} \mathrm{IMR}_{\mathrm{it}}+\lambda 3 \mathrm{COEQ}_{\mathrm{it}} \quad+\lambda_{4} \text { DEPVAR }_{\mathrm{it}}+\lambda_{5} \text { INTRATit } \\
& +\lambda_{6} \mathrm{DEPR}_{\mathrm{i}, \mathrm{t}}+\lambda_{7} \mathrm{AVCP}_{\mathrm{t}}+\lambda_{8} \ln \mathrm{ASSZ}_{\mathrm{i}, \mathrm{t}}+\varepsilon_{\mathrm{it}}
\end{aligned}
$$

Where,

Capital: The capital ratio for bank $\mathrm{i}$ at period $\mathrm{t}$.

RISK: The ratio "loans loss reserve/loans" for bank $\mathrm{i}$ at time $\mathrm{t}$.

IMR: Interest margin rate is the ratio inflation-adjusted "net interest margin / Asset" for bank $\mathrm{i}$ at period t. COEQ: Cost of equity for bank $i$ at period $t$.

DEPVAR: The demand deposits variability approximated by the ratio "deposits inflows/deposits outflows" for bank $\mathrm{i}$ at period $\mathrm{t}$.

INTRAT: Intermediation rate for bank i at period t measured by the ratio "loans/ deposits".

DEPR: Is the ratio "term deposit/ demand deposit" for bank $i$ at time $t$.

AVCP: The average capital adequacy ratio of all the banks of the sample at period $t$.

ASSZ: The size of the bank measured by total assets adjusted by the consumer price index. It is the natural $\log$ of total assets.

$\varepsilon_{\text {it }}$ : The error term.

\subsubsection{Multicollinearity Test}

To detect multicollinearity, we determinate the variance inflation factor (VIF) of the independent variable.

$\mathbf{5 7 | P}$ a g e

www.iiste.org 
The VIF measures how much the variance of a coefficient (square of the standard deviation) is increased because of collinearity.

R-squared and VIF of our model's independent variables are presented in Table 5.

Table 5 shows that none of the R-squared are near to 1.0. The variance of inflation factor (VIF) is always less than 5 . Thus, there is no multicollinearity problem.

\section{Empirical results}

\subsection{Results Significance}

Table 6 reports the regression results. We employ the Hausman specification to test whether the individual random effects are correlated with explanatory variables or not. The Breussch-Pagan Lagragian multiplier is used to test the significance of random effect in the model. It is also used to test the validity of the exogeneity of the explanatory variables.

The null hypothesis is rejected. Thus, the unobserved individual heterogeneity is uncorrelated with the explanatory variable. For our study, the within estimator is the best to perform.

According to Baltagi (1995), the random effects model FGLS estimates the error variance-covariance matrix. It assumes that the errors follow a panel specific autoregressive process. In the same time, the variance of the error is allowed to be different across units. He pointed out that the fixed effects model is appropriate when focusing on a specific set of $\mathrm{N}$ firms and when the inference is restricted to their behavior. In our study, this model is performed to make comparisons with previous studies. Both models will be run using feasible general least squares (FLGS) estimators.

It is worth noting that the signs of the coefficients are similar for all the regressions. In fact, we see that in the columns (1) (2) and (3), most of the coefficients magnitudes have not changed significantly.

The Table 6 shows that only three variables are negatively correlated with the dependent variable: The deposits ratio, the equity cost and the asset size. All the other variables are positively correlated with the capital ratio.

With the p-values significance of all the explanatory variables, we estimate that our model is a reliable.

The variance analysis shows that there is a strong relationship between all the explanatory variables and the dependent variable.

\subsection{Relationships'Signs}

The Asset size has a negative sign. So, it influences capital in the opposite direction. As it is shown in the Table 6, this variable might have an important impact on the equity level. This result is explained by the great increase of the total assets of all the Tunisian banks since 2002. The average rate of this increase is higher than that of the capital.

Our result is in accordance with those found by Alfon et al. (2005), Asarkaya and Ozcan (2007) and Gropp and Heider (2007). For Tunisian banks, this can be explained by the fact that the large banks have more depositors. The public banks have a lower ratio, because they have easy access to the financial market.

The sign of the deposits ratio coefficient is negative. A high deposits ratio means that the banks have more stable resources. Consequently, the share of all the deposits in the liabilities is high too. However, when the deposit ratios are high, the banks have costly deposits. But this cost remains lower than the cost of all the other funds. Therefore, the capital may relatively decrease.

According to the results of our regression, the banks that take higher risks have a higher capital ratio. They need to hold more capital to provide a buffer against losses. It is the same result as those of Rime (2001), Asarkaya and Ozcan (2007) and Gropp and Heider (2007). The coefficient of the variable "Risk" is the smallest. That means that risk influences the capital ratio less than the other variables.

$\mathbf{5 8} \mid \mathrm{P}$ a g e

www.iiste.org 
The coefficients of the equity cost are high. As Alfon et al. (2005), we find that it has a negative impact on capital. The Tunisian banks yearly pay a relatively important dividend. In this case, banks may be encouraged to have more loans because of the high equity cost.

Table 6 shows that the interest margin rate is significant at the 0.05 level in explaining the capital ratio. In our regression, its coefficients are positive and higher than all the other coefficients. Thus, earnings and capital are strongly related. The profitability is the first determinant of capital structure in Tunisian banks. Demirgüç-Kunt and Huizinga (2000), and Kuo and Lee (2003) found the same strong relationship.

There may be two way causalities between the equity cost and the interest margin rate in one hand, and the dependant variable in another one. Indeed, a higher profitability can infer an increase of the equity cost. In this case, the stockholders may require an increase of their dividends. The managers must determine the optimal retained earnings in order to increase capital to the desired level. This result shows that the Pecking order theory seems to be verified in the Tunisian banks.

We notice that the signs of the deposit ratio and the demand deposit variability are opposite. Table 6 shows that deposit variability has more influence on capital level. The deposit ratio has improved, but it has not compensated the increase of the demand deposits variability. This explains why the capital ratio has increased during the sample period.

The intermediation rate is significant at the 0.05 level. It influences positively the capital ratio. Its coefficient is high. This is due to the increase of the volume of activity. This evolution leads to higher risks and best profits. With These improvements, the equity might increase.

The sector average ratio is significant at the 0.01 level. A high average ratio may influence managers in increasing the capital. Each bank tries to have a ratio capital near or equal to the average. Its aim is to send a positive signal to the market and to the authorities. For commercial banks, there are self incentives to raise their capital. They seek to avoid the successive interferences by the central bank.

\section{Conclusion}

This study extends those carried out for the bank's capital ratio in the developed countries. We tried to explain the relationships between the capital ratio and the bank's variables. The proposed model has eight variables.

All our findings are in line with those of the $\mathrm{p}$ studies curried out in the industrial countries. Therefore, the relations developed in theory in the developed countries are also observed in the emerging ones.

The risk and the revenue have a positive impact on the dependent variable. They are significant in explaining the bank's capital excess. This excess is not due only to regulatory pressures.

The improvement of the intermediation rate and the asset size leads to a higher ratio. All the banks adjust it to make it close to the average. So, their capital increases.

The increase in the cost of equity reduces the capital. The deposit variability and the ratio of deposits have a negative effect on the capital.

The annual rates of the funds increase give us an idea on the financing order. The banks rely firstly on the deposits. Then, they raise their equity and finally, they make use of debts. This order is justified by the costs of the funds and by the high ROE. Thus, a specific Pecking Order seems to be verified in the Tunisian banks.

During the last decade, the rate of growth was high. All the banks had to finance the investments. So, their loans and their risk increased. This explains why their capital ratios were high.

If we take to account the economic conditions, the results might change. The bank's index of the management efficiency may affect the equity level. It is a new research question. 
European Journal of Business and Management

www.iiste.org

ISSN 2222-1905 (Paper) ISSN 2222-2839 (Online)

Vol 3, No.11, 2011

\section{References}

Ahmad R., Ariff A.and Michael, J.S. (2008). "The Determinants of Bank capital ratios in a developing Economy" CARF Working paper, March, Asia - Pacific Financial Markets, 15 (3-4), 255-272.

Alfon I., Argimón I., and Bascuñana-Ambrós, P. (2005),. "How Individual Capital Requirements Affect Capital Ratios in UK Banks and Building Societies?” Banco de España Working Paper, No: 0515.

Angbazo, L. (1997). "Commercial bank net interest margins, default risk, interest-rate risk, and off-balance sheet banking". Journal of Banking and Finance, 21(1), 55-87.

Asarkaya Yakup and Serkan Ozcan, S. (2007). "Determinants of capital structure in financial institutions: The case of Turkey" Journal of BRSA and Financial Markets, 2007, Vol 1, 1, 91-109.

Baltagi B.H. (1995). Econometric analysis of panel data. Chichester, Wiley.

Baltensperger E. (1973) "Optimal Bank Portfolio: The Liability Side" JahrbucherFur National Okonomie und Statistic, 187, 2, 147-160.

Berger, Allen N. (1995). "The Relationship Between Capital and Earnings in Banking." Journal of Money, Credit and Banking 27, 432-456.

Berger, Allen N., Richard J. Herring and Giorgio P. Szegö (1995). "The Role of Capital in Financial Institutions" Journal of Banking and Finance, 19 (June), 393-430.

Berger Allen N., De Young R., Flannery Mark J., Lee David and Oztekin Ozde (2008). "How do large banking organisations manage their capital ratios" Journal of financial research V 34, 2-3, 123-149.

Breusch, T.S. and Pagan A.R. (1980). "The Lagrange Multiplier Test and Its Applications to Model Specification in Econometrics", Review of Economic Studies, Vol 47, No. 1, 239-253.

Brewer, E., Kaufman, G and Wall, L. (2008). "Bank capital ratios across countries: Why do they vary?" Journal of Financial Services Researches, Vol 4, December, 177-201.

Demirgüç-Kunt Asli and Harry Huizinga (2000). "Financial Structure and Bank Profitability." (August), World Bank Policy Research Working Paper No. 2430.

Diamond, Douglas W. and Raghuram G. Rajan (2000). "A theory of bank capital”, Journal of Finance, 55, 2431-2465.

Gropp, Reint and Heider, Florian (2007). "What Can Corporate Finance Say about Banks' Capital Structures?" Review of Finance Forthcoming

Hausman, J.A. and Taylor W.E. (1981). "Panel Data and Unobservable Individual Effects", Econometrica, Vol 49, 6, 377-1398.

Jacques, K. and P. Nigro (1997). "Risk-Based Capital, Portfolio Risk, and Bank Capital: A Simultaneous Equations Approach". Journal of Economics and Business 49, 533-547.

Kentaro Iwatsubo (2007). "Bank Capital Shocks and Portfolio Risk: Evidence from Japan”. Japan and the World Economy, vol 19, 2, 166-186.

Kleff, V. and Weber, M. (2008). "How Do Banks Determine Capital? Empirical Evidence from Germany" Germain Economic Review, July, Vol 9, 3, 354-372.

Kohen M; and Santomero A.M. (1980). "Regulation of bank capital and portfolio risk" Journal of finance, $35,1235-1244$.

Kuo H. and Lee C.H. (2003). "The Determinants of capital structure of commercial Bank in Taiwan" International Journal of Management, Vol 20, 4, 515-522.

Marques O. M. and Santos C. M. (2003). "Capital Structure Policy and Determinants: Theory and Managerial Evidence" FFMA 2004 Basel Meetings paper.

Murinde V. and Yassen H. (2004). "The Impact of Basel Accords Regulation on Bank Capital and Risk"

$\mathbf{6 0 | P}$ a g e

www.iiste.org 
European Journal of Business and Management

www.iiste.org

ISSN 2222-1905 (Paper) ISSN 2222-2839 (Online)

Vol 3, No.11, 2011

Center for regulation and competition (CRC) conference, September.

Rime, B (2001). "Capital requirements and bank behaviour, Empirical Evidence of Switzerland", Journal of Banking and Finance, 25, 789-805.

Schaeck, Klaus and Čihák, Martin (2007). "Banking Competition and Capital Ratios" (September) IMF Working Paper No. 07/216.

Shrieves, Ronald E. and Drew Dahl (1992). "The Relationship Between Risk and Capital in Commercial Banks." Journal of Banking and Finance, 16, 439-457.

Wong, J., Choi, K., and Fong, T. (2005). "Determinants of the capital level of banks in Hong Kong". Hong Kong Monetary Authority Quarterly Bulletin, September 2005, 14-37.

Table 1: Tunisian banks' Capital ratio (\%)

\begin{tabular}{|c|c|c|c|c|c|c|c|}
\hline Ratios & 2002 & 2003 & 2004 & 2005 & 2006 & 2007 & 2008 \\
\hline Banking industry capital ratio & 9.6 & 9.3 & 11.6 & 12.4 & 11.3 & 11.0 & 11.2 \\
\hline Private banks capital ratio & 8.9 & 8.4 & 12.4 & 13.4 & 12.1 & 11.5 & 11.8 \\
\hline Public banks capital ratio & 10.2 & 10.8 & 10.1 & 10.0 & 9.3 & 10.0 & 10.3 \\
\hline
\end{tabular}

Source: Central bank of Tunisia and APB annual reports.

Table 2(a): Half annual means of variables

\begin{tabular}{|l|r|c|l|l|l|l|l|}
\hline Variables & \multicolumn{1}{|c|}{$2002-1$} & $2002-2$ & $2003-1$ & $2003-2$ & $2004-1$ & $2004-2$ & $2005-1$ \\
\hline Capital ratio & 9.73 & 9.89 & 10.37 & 10.76 & 11.08 & 11.32 & 11.54 \\
\hline Risk & 18.60 & 18.50 & 18.20 & 18.40 & 18.30 & 18.50 & 18.10 \\
\hline Net margin interest & 8.24 & 8.32 & 8.49 & 8.64 & 8.71 & 8.63 & 8.85 \\
\hline Equity cost & 12.41 & 11.12 & 11.12 & 11.05 & 11.05 & 10.83 & 10.83 \\
\hline Ratio of deposits & 48.23 & 48.58 & 49.86 & 50.16 & 51.79 & 52.34 & 54.42 \\
\hline Deposit variability & 52.11 & 53.23 & 53.16 & 54.37 & 55.24 & 56.48 & 57.64 \\
\hline Intermediation rate & 65.32 & 65.92 & 67.69 & 68.08 & 68.49 & 70.83 & 71.26 \\
\hline Ratio of the Sector & 10.62 & 10.87 & 11.39 & 10.74 & 11.36 & 13.71 & 12.58 \\
\hline Asset size & 13.82 & 13.34 & 14.53 & 14.61 & 15.08 & 14.70 & 15.24 \\
\hline
\end{tabular}

Table 2(b): Half annual means of variables

\begin{tabular}{|l|l|l|l|l|l|l|l|}
\hline Variables & $2005-2$ & $2006-1$ & $2006-2$ & $2007-1$ & $2007-2$ & $2008-1$ & $2008-2$ \\
\hline Capital ratio & 11.59 & 11.42 & 12.54 & 12.73 & 12.68 & 11.67 & 11.91 \\
\hline Risk & 17.80 & 17.70 & 17.20 & 16.90 & 17.10 & 16.70 & 16.40 \\
\hline Net margin interest & 8.93 & 8.86 & 9.07 & 8.98 & 9.12 & 9.21 & 9.38 \\
\hline Equity cost & 10.31 & 10.31 & 9.96 & 9.96 & 9.78 & 9.78 & 9.51 \\
\hline
\end{tabular}

$\mathbf{6 1 | P}$ a g e

www.iiste.org 
European Journal of Business and Management

ISSN 2222-1905 (Paper) ISSN 2222-2839 (Online)

Vol 3, No.11, 2011

\begin{tabular}{|l|l|l|l|l|l|l|l|}
\hline Ratio of deposits & 56.12 & 55.09 & 55.94 & 61.60 & 62.89 & 63.47 & 64.54 \\
\hline Deposit variability & 58.90 & 59.31 & 59.56 & 60.27 & 60.86 & 62.59 & 63.74 \\
\hline Intermediation rate & 72.14 & 72.76 & 72.88 & 72.44 & 73.57 & 74.71 & 75.62 \\
\hline Ratio of the Sector & 11.01 & 11.68 & 11.85 & 10.47 & 9.83 & 11.27 & 11.18 \\
\hline Asset size & 15.67 & 15.88 & 15.69 & 15.93 & 16.05 & 16.42 & 16.46 \\
\hline
\end{tabular}

RISK: the ratio "bank provision/loans"

IMR: interest margin rate is the ratio inflation-adjusted "interest margin / Assets".

COEQ: Cost of equity approximated by "Dividend/market value equity"

DEPVAR: the demand deposits variability approximated by the ratio "outflows of deposits /inflows"

INTRAT: intermediation rate approximated by the ratio "loans /deposits"

DEPR: is the ratio "term deposit/ demand deposit"

AVCP: the average capital adequacy ratio of all the banks of the sample,

ASSZ: the size of assets adjusted by the consumer price index. It is the natural log of total assets.

Table 3: Descriptive statistics

\begin{tabular}{|l|c|c|c|c|}
\hline Variables & Means & Std Dev & Min & Max \\
\hline Capital ratio & 11.3764 & 2.8943 & 8.64 & 12.98 \\
\hline Risk & 17.3634 & 11.0164 & 38.73 & 72.47 \\
\hline Net margin interest & 8.8164 & 3.6178 & 7.84 & 12.34 \\
\hline Equity cost & 9.4437 & 2.9452 & 8.41 & 10.83 \\
\hline Ratio of deposits & 55.4314 & 16.2687 & 39.23 & 72.38 \\
\hline Deposit variability & 57.6715 & 17.2657 & 48.23 & 63.74 \\
\hline Intermediation rate & 74.1664 & 14.5254 & 67.68 & 93.26 \\
\hline Ratio of the Sector & 10.9362 & 2.3173 & 10.80 & 11.90 \\
\hline Asset size & 15.6428 & 5.6128 & 13.34 & 16.46 \\
\hline
\end{tabular}

Table 4: Correlation matrix for dependent and explanatory variables

\begin{tabular}{|c|c|c|c|c|c|c|c|c|}
\hline AVCP & Capital ratio & Risk & IMR & COEQ & DPER & DEPVAR & INTRAT & ASEZ \\
\hline Capital ratio & 1 & & & & & & & \\
\hline Risk & 0.4474 & 1 & & & & & & \\
\hline IMR & 0.5464 & 0.4326 & 1 & & & & & \\
\hline
\end{tabular}

$62 \mid \mathrm{P}$ a g e

www.iiste.org 
European Journal of Business and Management

ISSN 2222-1905 (Paper) ISSN 2222-2839 (Online)

Vol 3, No.11, 2011

\begin{tabular}{|c|c|c|c|c|c|c|c|c|}
\hline COEQ & -0.2548 & 0.1496 & 0.0986 & 1 & & & & \\
\hline DPER & -0.1897 & 0.0687 & 0.2876 & -0.1879 & 1 & & & \\
\hline DEPVAR & 0.2167 & 0.1092 & -0.0832 & 0.1427 & -0.0169 & 1 & & \\
\hline INTRAT & 0.2452 & 0.0957 & -0.2417 & -0.2417 & 0.1528 & -0.8246 & 1 & \\
\hline ASEZ & -0.0742 & 0.0508 & 0.0529 & -0.0537 & 0.0884 & -0.0031 & -0.0568 & 1 \\
\hline AVCP $\quad 0.0937$ & -0.3112 & 0.0713 & -0.1818 & 0.0233 & -0.0697 & 0.0286 & -0.0162 & 1 \\
\hline
\end{tabular}

Table 5: Multicollinearity Test

\begin{tabular}{|l|c|c|}
\hline Variables & R-squared & VIF \\
\hline Risk & 0.195247 & 1.242617299 \\
Net margin interest & 0.426832 & 1.744689166 \\
Equity cost & 0.119425 & 1.135621608 \\
Ratio of deposits & 0.315139 & 1.460150307 \\
Deposit variability & 0.438634 & 1.781369017 \\
Intermediation rate & 0.463956 & 1.865518502 \\
Ratio of the Sector & 0.528914 & 2.122754465 \\
Asset size & 0.628545 & 2.692116137 \\
\hline
\end{tabular}


European Journal of Business and Management

ISSN 2222-1905 (Paper) ISSN 2222-2839 (Online)

Vol 3, No.11, 2011

Table 6: Regression results

\begin{tabular}{|c|c|c|c|}
\hline \multirow{2}{*}{ Explanatory variables } & \multicolumn{3}{|c|}{ Regression model } \\
\hline & Fixed effects (within) & Fixed effects(FGLS) & Random effects (FGLS) \\
\hline Constant & $20.4568(7.5249) * * *$ & $9.4685(3.9246) *$ & $8.8533(3.7654) * * *$ \\
\hline Risk & $0.0842(0.0157) *$ & $0.0598(0.0107) * *$ & $0.0748(0.0144) * *$ \\
\hline Net margin interest & $0.2758(0.1856) * *$ & $0.1985(0.1036) * *$ & $0.2151(0.1462) * * *$ \\
\hline Equity cost & $-0.1742 \quad(0.1286) * *$ & $-0.1637(0.0787) * * *$ & $-0.1389(0.4673) * * *$ \\
\hline Ratio of deposits & $-0.0819(0.0294) * * *$ & $-0.1048(0.0384) * * *$ & $-0.0962(0.0216) * * *$ \\
\hline Deposit variability & $0.1335(0.05179) *$ & $\begin{array}{lll} & 0.1537 & (0.4642) \\
* * * & & \end{array}$ & $0.1623(0.6174) * * *$ \\
\hline Interrmediation rate & $0.1172(0.0567)^{* *}$ & $0.1242(0.0587)^{*}$ & $0.1058(0.0463)^{* *}$ \\
\hline Ratio of the Sector & $0.0986(0.0465) * * *$ & $0.1179(0.0409) * * *$ & $0.0914(0.0319) * * *$ \\
\hline Asset size & $-0.1442(0.0856) * *$ & $-0.1318(0.0964) * *$ & $-0.1121(0.0886) * *$ \\
\hline Wald chi 2 & & 1742.38 & 537.92 \\
\hline R-Squared & 0.6724 & 0.6229 & \\
\hline Within & 0.7427 & 0.6927 & \\
\hline Between overall & 0.7182 & & 0.7463 \\
\hline F-test (p-value) & 0 & 0 & \\
\hline Nb observation & 80 & 80 & \\
\hline
\end{tabular}

Reported in parentheses are robust standard errors.

*** Significant at $1 \%$ level, ** significant at $5 \%$ level and * significant at $10 \%$ level. 
This academic article was published by The International Institute for Science, Technology and Education (IISTE). The IISTE is a pioneer in the Open Access Publishing service based in the U.S. and Europe. The aim of the institute is Accelerating Global Knowledge Sharing.

More information about the publisher can be found in the IISTE's homepage: http://www.iiste.org

The IISTE is currently hosting more than 30 peer-reviewed academic journals and collaborating with academic institutions around the world. Prospective authors of IISTE journals can find the submission instruction on the following page: http://www.iiste.org/Journals/

The IISTE editorial team promises to the review and publish all the qualified submissions in a fast manner. All the journals articles are available online to the readers all over the world without financial, legal, or technical barriers other than those inseparable from gaining access to the internet itself. Printed version of the journals is also available upon request of readers and authors.

\section{IISTE Knowledge Sharing Partners}

EBSCO, Index Copernicus, Ulrich's Periodicals Directory, JournalTOCS, PKP Open Archives Harvester, Bielefeld Academic Search Engine, Elektronische Zeitschriftenbibliothek EZB, Open J-Gate, OCLC WorldCat, Universe Digtial Library, NewJour, Google Scholar

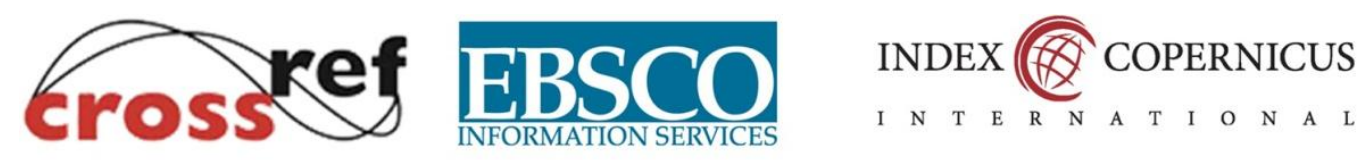

\section{Ounachener}

JournalTOCs

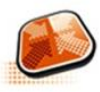

PKP | PUBLIC KNOWLEDGE PROJECT
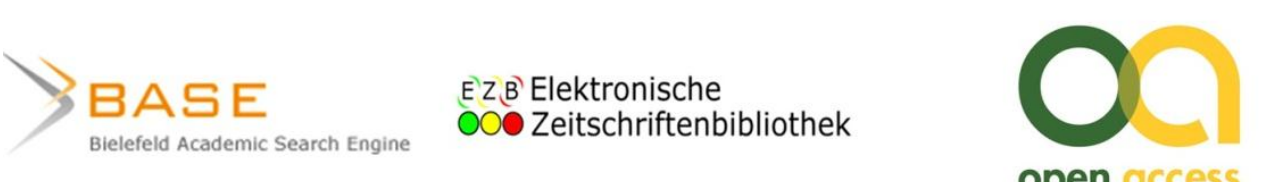

open access

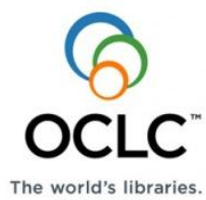

Connected.
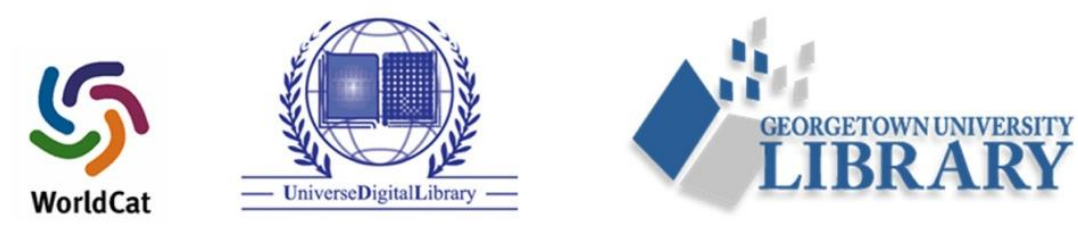